\title{
Related Factors With The Event Of Less Chronic Energy In Pregnant Women
}

\author{
Nurdika Parsya $^{1}$, Tenriwati ${ }^{2 *}$, Asnidar $^{3}$ \\ ${ }^{1}$ Nursing Student, Stikes Panrita Husada Bulukumba, Indonesia \\ ${ }^{2,3}$ Department of Nursing Stikes Panrita Husada Bulukumba, Indonesia
}

Corresponding author: Tenriwati

Email: tenriwatisalala@gmail.com

\begin{abstract}
Chronic energy deficiency (KEK) is a state of malnutrition in unfavorable conditions. This can be caused by lack of food and energy sources that contain micro substances. The need for pregnant women will increase from the usual exchange of almost all very active loads, especially in the third trimester. Therefore, an increase in the amount of food consumption needs to be increased, especially the consumption of food sources of energy to meet all the needs of the mother \& fetus, so if a little consumption will cause malnutrition or usually called KEK. The research objective was to determine the factors associated with less chronic incidence (KEK) in pregnant women in the working area of the Ponre Public Health Center, Bulukumba Regency in 2020. This research is a quantitative study, conducted with a descriptive analytic, using a cross-sectional study approach. Cross section design. The research sample was 44 respondents with Fisher's test. The results of this study indicate that there is a relationship between knowledge and the incidence of KEK in pregnant women using Fisher's test, the $p$ value is 0.004 ( $\mathrm{p}<0.05)$. , 05), there is no relationship between parity and SEZ occurrence using Fisher's test, the p value is obtained at 0.533 ( $p>0.05$ ) at the Ponre Public Health Center, Bulukumba Regency in 2020. The conclusion in this study is that there is a relationship between knowledge and economic level with the incidence of KEK, there is no relationship between parity and the incidence of KEK in pregnant women at Ponre Puskesmas, Bulukumba Regency. Suggestions for research to further expand the research sample not only to focus on pregnant women, researchers can also examine adolescents and also pregnant women who experience chronic energy deficiency (KEK), add research variables such as those that have not been researched, namely factors from disease infections and sources of disease. related to the incidence of KEK, Increasing the research period, with a longer period and it is hoped that more accurate and unusual research results can be obtained.
\end{abstract}

Keywords: Knowledge, Economic Level, Parity, Incidence Of KEK 


\section{PENDAHULUAN}

Kurang energy kronis (KEK) adalah suatu keadaan status gizi seseorang berada pada kondisi yang kurang baik. Hal ini dapat disebabkan karena kurangnya konsumsi pangan dan sumber energy yang mengandung zat mikro. Kebutuhan wanita hamil akan meningkat dari biasanya dimana pertukaran dari hampir semua beban terjadi sangat aktif terutama pada trimester III. Oleh sebab itu peningkatan jumlah konsumsi makan perlu ditambah, terutama konsumsi pangan sumber energy untuk memenuhi semua kebutuhan ibu \& janin, maka jika sedikit mengonsumsi akan menyebabkan malnutrisi atau biasanya disebut KEK.

Menurut WHO (world health organization) kejadian kekurangan gizi pada ibu hamil berkisar sekitar antara 20-48\% Angka kematian ibu (AKI) di jawa tengah selama tahun 2012 mencapai 678 (5,6\%) kasus, cenderung meningkat di banding pada tahun sebelumnya. Pada tahun 2011 jumlah AKI tercatat sebanyak 668(5,5\%) kasus dari 592.000 ibu hamil, sementara tahun 2012 jumlah AKI bertambah menjadi 678 (5,6\%) kasus dari 604.000 ibu hamil.(Wijayanti, 2019). Riset kesehatan dasar (Riskesdas 2018) Sulawesi Selatan proporsi wanita usia subur resiko KEK usia 15-19 tahun yang hamil sebanyak 38,5\% dan yang tidak hamil sebanyak 46,6\%. Pada usia 20-24 tahun yaitu sebanyak 30,1\% yang hamil dan yang tidak hamil sebanyak 30,6\%. Selain itu, pada usia 25-29 tahun adalah sebanyak 20,9\% yang hamil dan 19,3\% dan tidak hamil. Serta pada usia 30-34 tahun adalah sebanyak 21,4\% yang hamil dan $13,6 \%$ yang tidak hamil. Hal ini menunjukkan proporsi WUS (wanita usia subur) resiko KEK mengalami peningkatan dalam kurang waktu selama 7 tahun.(Puli et al., n.d.)

Berdasarkan data yang dapatkan dari Puskesmas Ponre jumlah ibu hamil yang mengalami/ menderita KEK pada tahun 2019 sebanyak 80 orang ibu hamil di bedakan dalam dua jalur yaitu jalur umum dan jalur BPJS, jalur umum sebanyak 13 orang dan jalur BPJS sebanyak 67 orang. Menurut penelitian yang dilakukan oleh sri handayani \& susi budianingrum tentang faktor yang mempengaruhi kekurangan energy kronis pada ibu hamil di dapatkan bahwa mayoritas ibu hamil memiliki pengetahuan dengan kategori kurang yaitu sebanyak $(69,1 \%)$. Disimpulkan sebagian besar ibu hamil yang megalami KEK adalah ibu hamil yang memiliki pengetahuan kurang tentang gizi dengan status ekonomi rendah, dan dapat pula di sebabkan dengan jumlah anak yang terlalu banyak.(Adriani \& Susilawati, 2019).

Upaya yang dilakukan oleh pemerintah dalam hal penanggulangan masalah KEK selain program pemberian makanan tambahan (PMT) pemerintah juga memberikan upaya program 
seribu hari pertama kehidupan (HPK) yaitu program nasional untuk menyelamatkan kehidupan ibu dan bayi yang dimulai dari seribu HKP yaitu setiap sebulan sekali disetiap puskesmas semua ibu hamil, bersalin, nifas, bayi dan balita harus dilayani, ditimbang berat badan dan dilihat status gizinya, tetapi kejadian KEK pada ibu hamil masih mengalami peningkatan tiap tahun maka diperlukan penelitian selanjutnya.(Energi et al., 2017). Tujuan penelitian ini adalah untuk mengetahui faktor-faktor apasaja yang berhubungan dengan kejadian kurang energy kronis (kek) pada ibu hamil di Puskesmas Ponre Kabupaten Bulukumba Tahun 2020.

\section{BAHAN DAN METODE}

\section{Desain Penelitian}

Jenis penelitian ini merupakan penelitian kuantitatif dimana penelitian ini menggunakan desain penelitian dengan rancangan Cross secsional study. ini merupakan rancangan penelitian dengan melakukan pengukuran atau pengamatan pada saat bersamaan variabel dependen dan variable independent pada satu saat tertentu. Hal ini berarti tiap subjek hanya wawancara satu kali dan pengukuran variabel subjek pada saat pemeriksaan tersebut. (Nursalam, 2016) Dengan demikan pada study Cross sectional peneliti tidak melakukan tindak lanjut terhadap hasil pengukuran.

\section{Populasi dan Teknik Sampel}

Populasi adalah wilayah generalisasi atau seluruh subjek/objek data yang mempunyai kuantitas dan tertentu yang akan diteliti, karakteristik tertentu yang ditetapkan oleh peneliti untuk dipelajari dan kemudian ditarik kesimpulannya (tine donsu \& Msi, 2019). Populasi dalam penelitian ini adalah semua ibu hamil yang menderita kurang energy kronis (KEK) sebanyak 80 ibu hamil yang ada pada wilayah kerja puskesmas ponre kabupaten bulukumba.

Sampel merupakan bagian jumlah dari populasi atau merupakan karakteristik yang dimiliki oleh populasi tersebut.(tine donsu \& Msi, 2019)Sampel dalam penelitian ini berjumlah 44 orang ibu hamil yang mengalami dan yang tidak mengalami KEK Tehnik sampling yang digunakan pada peneltian ini adalah purposive sampling.

\section{Instrumen Pengumpulan Data}

Instrument penelitian adalah suatu alat yang digunakan oleh peneliti untuk mengobservasi, mengukur, atau menilai suatu fenomena dan juga secara tertulis berupa pedoman wawancara, pengamatan, dan daftar pertanyaan yang sudah disiapkan oleh peneliti untuk mendapatkan informasi dan responden. (Nursalam, 2016) 


\section{Analisa Data}

Data dianalisis berdasarkan skala ukur dan tujuan penelitian dengan menggunakan perangkat lunak program komputerisasi. Data dianalisis secara : (1) Analisis Univariat, Analisis dilakukan untuk melihat proporsi. (2) Analisis Bivariat, Uji bivariat dilakukan untuk mencari hubungan antara variabel independen dan variabel dependen dengan uji yang digunakan adalah chi Square bila memenuhi syarat. Kemaknaan yang diterima apabila $\mathrm{p}<0,05$.

\section{HASIL}

Berdasarkan table 1,maka dapat diketahui bahwa karakteristik responden berdasarkan umur dominan yang remaja akhir sebanyak 22 responden $(50,0 \%)$ sedangkan karasteristik responden umur dewasa awal sebanyak 19 responden $(43,2 \%)$ di bandingkan umur dewasa akhir sebanyak 3 responden $(6,8 \%)$. Karakteristik responden berdasarkan pendidikan dominan responden yang berpendidikan SD sederajat sebanyak 16 responden $((36,4 \%)$ karakteristik responden berdasarkan pendidikan SMP sebanyak 12 responden (27,3\%) karakterisktik responden berdasarkan pendidikan SMA sebanyak 11 responden $(25,0 \%)$ karakteristik responden berdasarkan pendidikan peguruan tinggi sebanyak 4 responden $(9,1 \%)$. Karakteristik responden berdasarkan dengan status pekerjaan dimana lebih dominan responden yang tidak bekerja sebanyak 39 responden $(88,6 \%)$ dibandingkan dengan responden yang bekerja sebanyak 5 responden $(11,4 \%)$.

Tabel 1 Distribusi Frekuensi Berdasarkan Karakteristik Responden

\begin{tabular}{|c|c|c|}
\hline Karakteristik responden & Frekuensi & Persentase (\%) \\
\hline \multicolumn{3}{|l|}{ Umur } \\
\hline Remaja akhir (usia 17-25 tahun) & 22 & $50,0 \%$ \\
\hline Dewasa awal (usia 26-35 tahun) & 19 & $43,2 \%$ \\
\hline Dewasa akhir (usia 36-45 tahun) & 3 & $6,8 \%$ \\
\hline \multicolumn{3}{|l|}{ Pendidikan } \\
\hline SD & 16 & $36,4 \%$ \\
\hline SMP & 12 & $27,3 \%$ \\
\hline SMA & 11 & $25,0 \%$ \\
\hline Perguruan Tinggi & 5 & $11,4 \%$ \\
\hline \multicolumn{3}{|l|}{ Pekerjaan } \\
\hline Bekerja & 5 & $11,4 \%$ \\
\hline Tidak Bekerja & 39 & $88,6 \%$ \\
\hline Total & 44 & $100 \%$ \\
\hline
\end{tabular}

Berdasarkan table 2 dari hasil penelitian ini dari 44 responden dominan responden yang mengalami kurang energy kronis (KEK) sebanyak 24 responden (54,5\%). Dibandingkan dengan tidak mengalami KEK sebanyak 20 responden $(45,5 \%)$. Tingkat pengetahuan kurang 
dominan paling banyak yaitu sebanyak 26 responden $(59,1 \%)$ dibandingkan dengan tingkat pengetahuan cukup sebanyak 18 responden (40,9\%). Jumlah responden yang berpenghasilan rendah lebih dominan banyak yaitu sebanyak 21 responden $(47,7 \%)$ jumlah responden yang berpenghasilan tinggi sebanyak 12 responden (27,3\%) jumlah responden yang berpenghasilan sedang sebanyak 9 responden (20,5\%) dibandingkan dengan responden yang berpenghasilan sangat tinggi sebanyak 2 responden (4,5\%). Hasil penelitian dari 44 jumlah responden dengan kehamilan primipara lebih dominan banyak yaitu sebanyak 25 responden $(56,8 \%)$ dibandingkan dengan jumlah kehamilan multipara sebanyak 13 responden (29,5\%) sedangkan kehamilan grandemultipara sebanyak 6 responden $(13,6 \%)$.

Tabel 2. Jumlah Responden Berdasarkan kejadian KEK, tingkat pengetahuan, penghasilan dan Paritas

\begin{tabular}{ccc}
\hline Kejadian KEK & Frekuensi & Persentase (\%) \\
\hline KEK & 24 & $54,5 \%$ \\
Tidak KEK & 20 & $45,5 \%$ \\
\hline Tingkat pengetahuan & Frekuensi & Persentase (\%) \\
\hline Baik & 0 & $0 \%$ \\
Cukup & 18 & $40,9 \%$ \\
Kurang & 26 & $59,1 \%$ \\
\hline Penghasilan & Frekuensi & Persentase (\%) \\
\hline Sangat tinggi & 2 & $4,5 \%$ \\
Tinggi & 12 & $27,3 \%$ \\
Sedang & 9 & $20,5 \%$ \\
\hline Rendah & 21 & $47,7 \%$ \\
\hline Kehamilan & Frekuensi & Persentase $(\%)$ \\
\hline Primipara & 25 & $56,8 \%$ \\
Multipara & 13 & $29,5 \%$ \\
Grandemultipara & 6 & $13,6 \%$ \\
\hline Total & $\mathbf{4 4}$ & $\mathbf{1 0 0 \%}$ \\
\hline
\end{tabular}

Hasil analisis dengan menggunakan uji fisher pada tabel 3 diperoleh nilai significancy sebesar 0,004 $(p<0,05)$, maka dapat disimpulkan bahwa "terdapat hubungan antara tingkatpengetahuan dengan kejadian kurang energy kronis (KEK) pada ibu mail di Puskesmas Ponre Kabupaten Bulukumba."Hasil analisis dengan menggunakan uji fisher diperoleh nilai significancy sebesar 0,003 ( $p<0,05)$, maka dapat disimpulkan bahwa "terdapat hubungan antara tingkat penghasilan dengan kurang energy kroonis (KEK) pada ibu hamil di Puskesmas Ponre Kabupaten Bulukumba. Hasil analisis dengan menggunakan uji fisher di peroleh nilai significancy sebesar 0,533 ( $p>0,05)$, maka dapat disimpulkan bahwa "tidak terdapat hubungan 
antara peritas atau jumlah kehamilan dengan kejadian kurang energy kronis (KEK) pada ibu hamil di Puskesman Ponre Kabupaten Bulukumba.

Tabel 3. Hubungan Berdasarkan Pengetahuan,Tingkat Pendidikan Dan Paritas Dengan Kejadian KEK

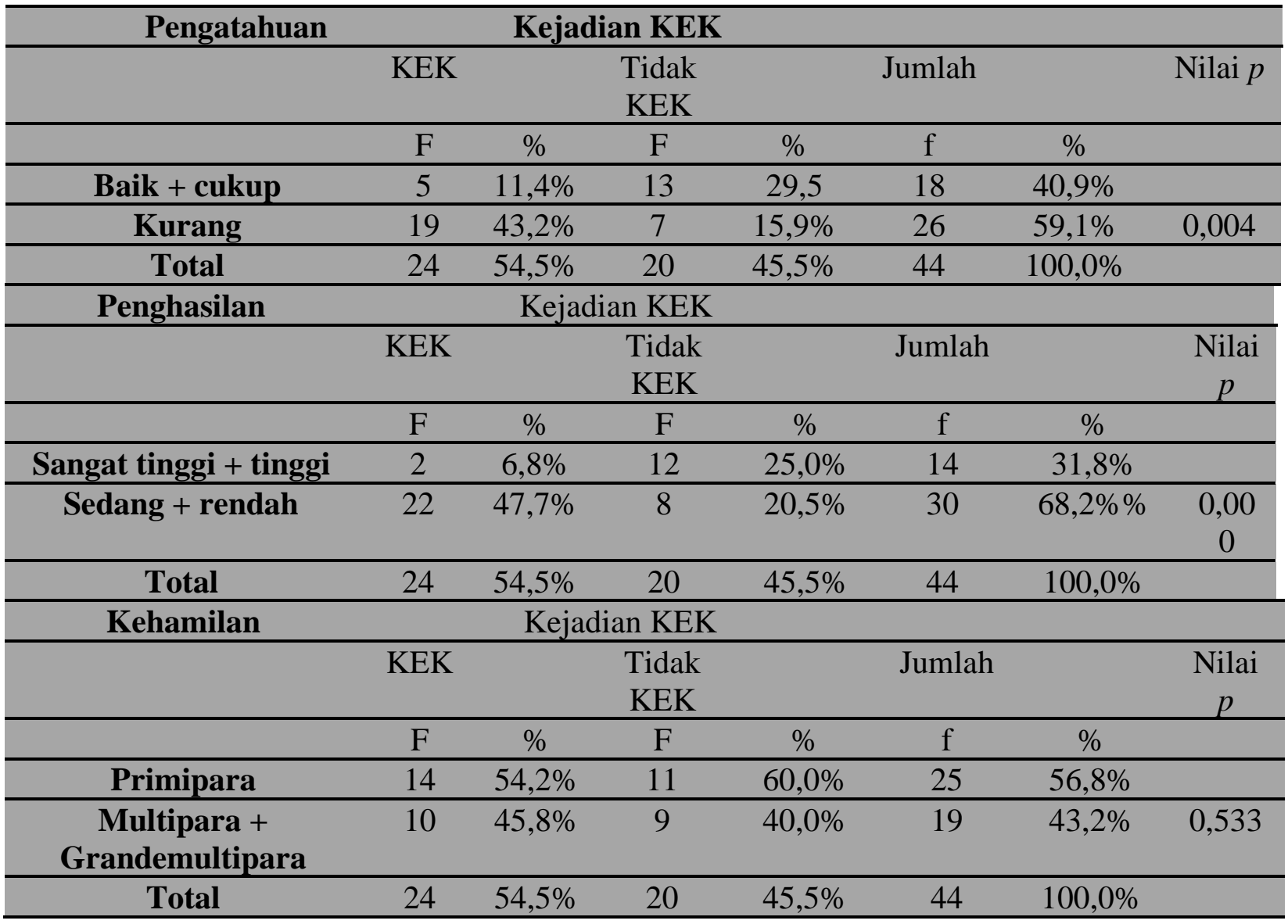

\section{PEMBAHASAN}

Pengetahuan merupakan hasil setelah orang melakukan pengindraan terhadap suatu objek tertentu. Meunurut (Notoadmojo, 2012) pengindraan terjadi melaului pancaindra manusia yakni : penglihatan, pendengaran, penciuman, rasa dan raba. Sebagian besar pengetahuan manusia diperoleh melalui mata dan telinga. Pengetahuan sangat berpengaruh terhadap perilaku, terutama dalam perilaku pola makan yang menganggap berat badan tidak bertambah selama hamil itu biasa, juga perilaku tidak memeriksa kandungannya kepetugas kesehatan sehingga tidak terdeteksi dengan dini kejadian KEK.

Peneliti berasumsi bahwa dalam penelitian ini ibu hamil yang berpengetahuan baik sebanyak 18 responden $(40,9 \%)$ diantaranya ibu hamil yang tidak mengalami KEK sebanyak 
13 responden $(29,5 \%)$ ibu hamil yang mengalami KEK sebanyak 5 responden $(11,4 \%)$ ke 5 responden yang masih mengalami KEK ini sedangkan berpengetahuan cukup tetapi masih menagalami KEK itu karena di sebabkan oleh faktor lain yaitu dilihat kembali dari tingkat penghasilan ke 5 responden ini berpenghasilan rendah sehingga saya mengatakan bahwa dari penghasilan tersebut sekalipun ibu hamil ini berpengetahuan cukup tetapi penghasilan yang di dapatkan perbulannya tidak mampu mencukupi gizi yang dibutuhkan ibu saat hamil. Sedangkan jumlah responden yang berpengetahuan kurang sebanyak 26 responden $(59,1 \%)$ diantaranya ibu hamil yang mengalami KEK sebanyak 19 responden (43,2\%) ibu hamil yang tidak mengalami KEK sebanyak 7 responden $(15,9 \%)$ di pengetahuan kurang juga menunjukkan masih ada responden yang tidak mengalami KEK sebanyak 7 responden ini juga dapat dilihat dari faktor penghasilannya ke 7 responden tersebut berpenghasilan tinggi dan sangat tinggi, sehingga saya mengatakan bahwa yang membuat ibu hamil ini tidak mengalami KEK sekalipun pengetahuannya kurang tetapi mereka mampu memenuhi kebutuhannya saat hamil karena disebabkan oleh penghasilan yang berkecukupan.

Menurut teori pendapatan merupakan faktor yang menentukan kualitas dan kuantitas makanan. Pada rumah tangga berpendapatan rendah, sebanyak 60-80\% dari pendapatan riilnya dibelanja untuk membeli makanan. Artinya pendapatan tersebut 70-80\% energy dipengaruhi oleh karbihidrat (beras dan penggatinya) dan hanya 20\% dipenuhi oleh sumber energy lainnya seperti lemak dan protein.(Adriani \& Susilawati, 2019)

Peneliti berasumsi bahwa, pada penelitian ini jumlah penghasilan sangat tinggi dan tinggi sebanyak 14 responden $(31,8 \%)$ diantaranya ibu hamil yang tidak mengalami KEK sebanyak 12 responden $(25,0 \%)$ dan jumlah ibu hamil yang mengalami KEK sebanyak 2 responden $(6,8 \%)$ dari 2 responden ini kenapa masih ada yang KEK padahal penghasilan sangat tinggi dan tinggi dapat dilihat kembali dari faktor lain seperti pendidikan dan pengetahuan responden, 2 responden tersebut berpendidikan SD dan SMP dari skor pengetahuan yang kurang. Jadi peneliti menyimpulkan bahwa 2 responden ini mengalami KEK dilihat dari faktor pengetahuannya sekalipun responden tersebut berpenghasilan sangat tinggi dan tinggi. Sedangkan jumlah responden yang berpengetahuan kurang sebanyak 30 responden $(68,2 \%)$ diantaranya ibu hamil yang mengalami KEK sebanyak 22 responden $(47,7 \%)$, ibu hamil yang tidak mengalami KEK sebanyak 8 responden (20,5\%). Dsini terdapat juga ibu hamil yang tidak mengalami KEK padahal responden tersebut berpenghasilan rendah sebanyak 8 responden 
kenapa masih ada yang tidak mengalami KEK padahal penghasilannya kurang, karena bisa dilihat dari tingkat pendidikan ibu hamil pada 8 responden tersebut ada ibu hamil yang berpendidikan S1 dan SMA sekalipun masih ada yang berpendidikan SD tetapi skor dari pengetahuan responden tersebut dalam kategori cukup. Dari itu saya menyimpulkan bahwa 8 responden tersebut yang berpenghasilan kurang dan sedang tapi tidak mengalami KEK dilihat dari faktor pengetahuan dan pendidikan.

Paritas adalah status seorang wanita sehubungan dengan jumlah anak yang pernah dilahirkan paritas yang termasuk dalam faktor resiko tinggi dalam kehamilan adalah grandemultipara, dimana hal ini dapat menimbulkan keadaan mempengaruhi optimalisasi ibu maupun janin pada kehamilan yang dihadapi. Dapat disimpulakn bahwa paritas yang tidak lebih dari 4 tidak beresiko mengalami gangguan, sehingga dalam penelitian ini penulis menyimpulkan multipara dan primipara tidak termasuk dalam resiko tinggi kehamilan.(Kek et al., 2017)

Peneliti berasumsi bahwa salah satu faktor yang berhubungan dengan kejadia kurang energy kroonis adalah faktor paritas yang dimana dijelaskan pada teori bahwa kehamilan yang berulang bisa menyebabkan ibu hamil tidak memperhatikan pola makan atau malas makan karena menurutnya sudah biasa tanpa ia sadari itu dapat membahayakan janin yang dikandungnya apalagi pada kehamilan 1 sampai sekarang ibu hamil tersebut mengalami mual muntah sehingga dapat mengakibatkan kurangnya protein dalam tubuh sehingga responden tersebut lebh rentang mengalami KEK. Tetapi pada penelitian ini pada paritas multipara dan grandemultipara sekalipun sebanyak 10 ibu hamil yang mengalami KEK tetapi masih ada ibu hamil yang tidak mengalami KEK pada kehamilan multipara itu disebabkan karena rata-rata berpenghasilan tinggi dan sedang dan juga beberapa responden yang yang tingkat pengetahuannya cukup. Sehingga ia bisa mengurangi dampak dari jumlah paritas ini yang bisa mengalami kurang energy kronis pada saat hamil.

\section{KESIMPULAN DAN SARAN}

Terdapat hubungan antara tingkat pengetahuan dengan kejadian kurang energy kronis (KEK) pada ibu hamil di Puskesmas Ponre Kabupaten Bulukumba dari hasil uji statistic dengan menggunakan uji fisher diperoleh nilai significancy sebesar 0,004( $p<0,05)$, Terdapat hubungan antara penghasilan dengan kejadian kurang energy kronis (KEK) pada ibu hamil di Puskesmas Ponre Kabupaten Bulukumba dari hasil uji statistic dengan menggunakan uji fisher diperoleh 
nilai significancy sebesar $0,003(p<0,05)$, Tidak terdapat hubungan antara paritas dengan kejadian kurang energy kronis (KEK) pada ibu hamil di Puskesmas Ponre Kabupaten Bulukumba dari hasil uji statistic dengan menggunakan uji fisher diperoleh nilai significancy sebesar $0,533(p<0,05)$.

Dapatkan kami sarankan bahwa sampel penelitian tidak hanya berfokus pada ibu hamil peneliti juga dapat meneliti remaja dan juga ibu partus yang mengalami kurang energy kronis (KEK). Menambah variabel penelitian seperti yang tidak sempat diteliti yaitu faktor dari penyakit infeksi dan sember-sumber lainnya yang berhubungan dengan kejadian KEK. Menambah reriode penelitian, dengan periode yang lebih panjang dan diharapkan dapat memperoleh hasil penelitian yang lebih akurat dan tidak biasa.

\section{DAFTAR PUSTAKA}

Energi, K., Kek, K., \& Kabupaten, D. I. (2017). PERAN KEBIJAKAN PEMERINTAH DAERAH DALAM MENANGGULANGI THE ROLE OF THE LOCAL GOVERNMENT POLICY IN ERADICATION OF. 7(November), 113-122.

Febriyeni, F. (2017). Faktor-Faktor Yang Berhubungan Dengan Kejadian Kekurangan Energi Kronis Pada Ibu Hamil. Human Care Journal, 2(3). https://doi.org/10.32883/hcj.v2i3.78

Indriany, I., Helmyati, S., \& Paramashanti, B. A. (2016). Tingkat sosial ekonomi tidak berhubungan dengan kurang energi kronis (KEK) pada ibu hamil. Jurnal Gizi Dan Dietetik Indonesia (Indonesian Journal of Nutrition and Dietetics), 2(3), 116. https://doi.org/10.21927/ijnd.2014.2(3).116-125

Kek, K., Ibu, P., Di, H., Puskesmas, U., \& Watampone, B. T. (2017). Faktor - faktor yang berhubungan dengan kekurangan energi kronik (kek) pada ibu hamil di uptd puskesmas ajangale. 11, 57-62.

Nugrahenny, A. sulisyawati \&. (2013). Asuhan kebidanan pada ibu bersalin. Salemba medika.

Palimbo, A. (2013). Hubungan Pengetahuan Dan Sikap Ibu Hamil Terhadap Kejadian Kekurangan Energi Kronis (KEK). Dinamika Kesehatan Jurnal Kebidanan Dan Keperawatan, 5(2), 1-10. https://doi.org/10.1111/jog.12159

Philipus, S. (2011). sosiologi dan politik. Salemba medika.

Puli, T., Thaha, A. R., Program, A. S., Ilmu, S., Fakultas, G., Masyarakat, K., \& Hasanuddin, 
U. (n.d.). HUBUNGAN SOSIAL EKONOMI DENGAN KEKURANGAN ENERGI KRONIK (KEK) PADA WANITA PRAKONSEPSI DI KOTA MAKASSAR Socio-

Economic Relations with Chronic Energy Deficiency (CED) for Preconceptions Women in Makassar. 1-7.

Setiadi. (2013). konsep dan prkatik penulisan riset keperawatan. GRAHA ILMU.

Soerjono, S. (2010). sosiologi suatu pengantar. rajagrafindo persada...

Sulistyawati, Ari, Nugraheny, E. (2013). Asuhan kebidanan pada masa kehamilan. Salemba medika.

Syamsuddin. (2015). Pedoman praktis metode penelitian internal, . CV.wade Group.

tine donsu, D. jenita doli, \& Msi, S. (2019). Metodologi penelitian keperawatan. PT.Pustaka Baru.

Waluyo, K. (2010). memahami gizi untuk ibu hamil dan ibu menyusui. PT. Puri Delco.

Walyani. (2015). Asuhan kebidanan pada kehamilan. Pustakabarupress.

Wijayanti, I. T. (2019). Pola Makan Ibu Hamil Yang Mempengaruhi Kejadian Kek Di Puskesmas Gabus I Kabupaten Pati. Jurnal SMART Kebidanan, 6(1), 5. https://doi.org/10.34310/sjkb.v6i1.226 